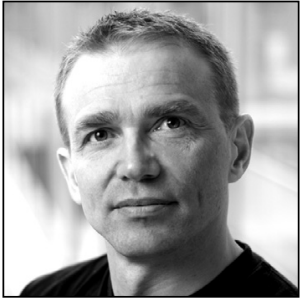

Claes Martinson

Associate Professor

University of Gothenburg

\title{
The Scandinavian Approach to Property Law, Described through Six Common Legal Concepts
}

\section{Contribution to the European project?}

It is interesting to see other lawyers' reactions when they encounter the Scandinavian approach to property law. ${ }^{{ }_{1}}$ In fact, it is interesting to see the reactions of Scandinavian lawyers when they realise that we have an approach that others react upon. One purpose with this article is to provoke more of these reactions. Ideally, doing so could lead to some reflections on what we all do as property lawyers. The Scandinavian approach is not only a matter of legal culture. It also brings a perspective that can be useful for the understanding of law and what law is. In a time of far-reaching internationalisation of law, thoughts such as these can be rather helpful and contributing. One example of this is that the Scandinavian approach to property law played a role in the Draft Common Frame of Reference (DCFR) project. The approach served as a work method in development of the DCFR rules on transfer of ownership. ${ }^{{ }_{2}}$

Regardless of the methodological contribution, the DCFR rules did not come to share the characteristics of the Scandinavian approach. ${ }^{*}{ }^{3}$ This illustrates that the approach can be of use while not governing all choices. For avoidance of misunderstanding, it might be necessary to stress this fact. ${ }^{*} \mathrm{I}$ am not a prophet proclaiming the Scandinavian approach better than others. My ambition with this article is just to explain a perspective on property law that, in the ideal case, might contribute with some reflections on what we all do as property lawyers.

One thing that property lawyers do is to involve objects in their argumentation. Property objects are, for obvious reasons, important in property law. All objects are however, conceptual. Therefore every property lawyer faces the risk of employing conceptual logic, for better or worse. The preference in the Scandinavian approach is very much against conceptual logic. A very general description of the Scandinavian approach is that it is relational to a fairly great extent. Scandinavian property lawyers deal with relations and keep each

1 I have illustrated some typical reactions in C. Martinson. Ejendomsrettens overgang - Norden kontra verden. Nordiska Juristmötet 2008. See http://jura.ku.dk/njm/38/martinson-claes/.

2 W. Faber. Overview of content and methodology: Book VIII of the DCFR. - The Edinburgh Law Review 2010 (14)/3, p. 502.

3 The DCFR uses a unitary structure; see Book VIII, Article 2:101 and 2:201.

4 It is, of course, up to the reader to judge what I do. See, for example, the reasonable opinion of Professor G.L. Gretton. Review. - The Edinburgh Law Review 2009 (13), p. 170. For whatever the knowledge of it is worth, my intention is sincerely what I say it is. 
of them apart without connecting a solution of one problem to the solution of a problem in another relation. We also think that context matters. This has effects on how we use legal concepts.

It is not self-evident how the Scandinavian approach should be presented. As I have mentioned above, Scandinavian lawyers do not have a general notion of having a particular approach. That is not a topic in the legal education, nor has it been a theme in legal research. The fact that the approach stems from legal theoretical discourse in 1900-1975 does not mean that there is any description of an approach as such. What I do here is to construct such a description. I have done this from a general analysis of legal argumentation in Scandinavia, and primarily the Swedish argumentation. My description depicts the Scandinavian approach in a rather consequent and distinct way.

I have chosen to do my presentation by using concepts in a way that I hope can function as common ground. This is not only to aid the reader, but also to allow some comparative remarks. Each of the following sections deals with a legal concept that is more or less familiar to quite a few lawyers. The concepts are ownership, transfer of ownership, unjustified enrichment, the coming into existence of a claim, acessio, and traditio.

\section{Ownership}

To explain the Scandinavian legal approach to ownership, I like to use a recent case from the European Court of Human Rights, in Strasbourg: the case Gillberg v. Sweden, from April 2012. ${ }^{*} 5$

Gillberg is a university professor in child and adolescent psychiatry. ${ }^{* 6} \mathrm{He}$ and his team conducted a lengthy large-scale study of pre-school-age children that looked at hyperactivity and attention-deficit disorders in children (ADHD and DAMP). Gillberg had promised confidentiality to the volunteers in the study, since the research involved a very large quantity of privacy-sensitive data on the children and their relatives. This became a problem after the study was finished and the results presented in several books and articles. Two people, a researcher in sociology and a paediatrician, wanted access to the research file. They claimed support for this claim in Swedish legislation on public access to official records. ${ }^{* 7}$ Gillberg refused to give them access, because of the promise of confidentiality. He refused even though the Administrative Court of Appeal had decided that he had to grant access. It made no difference that the vice-chancellor of the University of Gothenburg's threatened to bring him before the Public Disciplinary Board if he did not. Gillberg's team of researchers supported him, and the research file was never revealed. Three of Gillberg's colleagues destroyed it. Since it was voluminous, this took several days.

Gillberg was convicted for misuse of office under Chapter 20, Article 1 of the Swedish Penal Code. So was the vice-chancellor of the university, since he had failed to ensure that the documents were available for release.

Professor Gillberg sued Sweden before the European Court of Human Rights in Strasbourg. He claimed that he had a right under Article 8 of the Convention for the Protection of Human Rights and Fundamental Freedoms not to impart confidential information and that this right had been breached by his criminal conviction. He also claimed that he had a negative right, within the meaning of Article 10 of the convention, not to supply the disputed research material.

The above is but a brief description of the case, but it is enough for an understanding of what the judges did in their decision. From a Scandinavian approach to law, the judges developed very surprising reasoning. What they did was to use the concept of ownership to decide the case. They said this:

“... the crucial question can be narrowed down to whether the applicant, as a public employee, had an independent negative right within the meaning of Article 10 of the Convention not to make the research material available, although the material did not belong to him but to his public employer, the University of Gothenburg, and despite the fact that his public employer-the university-actually intended to comply with the final judgments of the Administrative Court of Appeal granting $\mathrm{K}$ and $\mathrm{E}$ access to its research material on various conditions, but was prevented from so doing because the applicant refused to make it available. [...] In the Court's view, finding that the applicant

\footnotetext{
Gillberg v Sweden, 41723/o6, Strasbourg, 3 April 2012.

http://en.wikipedia.org/wiki/Christopher_Gillberg.

Tryckfrihetsförordning (1949:105), Chapter 2.
} 
had such a right under Article 10 of the Convention would run counter to the property rights of the University of Gothenburg. ${ }^{*}{ }^{8}$

From a Scandinavian approach to law, this is indeed a remarkable way of reasoning. It is remarkable because ownership of the documents was not at all the issue. The issue concerned the interests that the parties had with respect to disclosure of certain information.

By bringing in the concept of ownership, the judges moved the attention away from the real issue." ${ }^{* 9}$ What they say is the crucial question is an issue that has nothing at all to do with the real interests behind the conflict. In their crucial reasoning, they decide the case by referring to a different set of interests. This effect is amplified by the fact that the judges actually consider ownership of the physical objects. They change the object of the conflict from the information into the papers.

The judges make their decision by employing clear simplification. This can be illustrated by the question of whether the decision would have been different if Gillberg had himself provided all of the paper material needed for the study and kept all of the documents produced at home. Since academic projects in medicine are often carried out in co-operation with private companies, something of this sort could easily have occurred. The question therefore shows that such simplified reasoning can lead to haphazard results. From the Scandinavian perspective, it is important to avoid haphazard results and reasoning divorced from the real interests at hand. In that view it is seen as too simplistic to reason with conceptual logic as the Strasbourg judges did. The legitimacy of a decision should proceed mainly from the strength of the argumentation, not from formal authority alone.

With the Scandinavian approach the concept of ownership would not have been used in construction of the solution. In addition the Strasbourg judges' reasoning would have been excluded also for another reason. Their reasoning lacked assumptions as to the consequences of the normative implications, and such assumptions are important in Scandinavian argumentation. The possible consequence of academic researchers in future using private papers for their academic projects would have formed part of a valid argument. The judges would then have contemplated whether this would open an easy way to avoid public access. If so, the decision could well have been that ownership of the papers is of less importance than public access. In the Scandinavian approach, legal issues are to be resolved not only by means of the norms and the concepts but also through striking a balance between the interests behind the norms and concepts. Taking the possible consequences into account is one of the ways to assure that such a balance is striven for and that the underlying interests are not forgotten.

The Strasbourg judges' decision also illustrates the extent to which legal reasoning can lack consideration of the interests behind the concepts. The decision is truly remarkable in this sense, especially in view of the purpose of the Strasbourg court. The court should have been deciding on the limits for protection of some interests of individuals versus the state. In this specific court, the concept of ownership is, by convention, used to grant individuals protection against the state. ${ }^{* 10}$ What the judges did, was however to use the concept against the individual. It was not used to prevent the state from interfering with the rights of the individual but for something else. From what we can read, the judges used the concept instrumentally and came to their conclusion via conceptual logic. ${ }^{* 11}$

The reasoning in this case is, in other words, a clear example of something other than the Scandinavian approach. ${ }^{*}$ It is an illustrative example of how the concept of ownership can be used as a tool that

8 Sections 92-93 of the judgement.

9 It should be pointed out that the judges' reasoning in the case encompasses much more than I have mentioned here. Therefore, the decision can, and should, be described as a wiser and more elaborated decision. What I do in this article is accord much weight to the fact that the judges proclaim that 'the crucial question' is that of ownership of the material.

10 One might remark that the ownership/property rights article of the 1952 additional protocol to the Convention for the Protection of Human Rights and Fundamental Freedoms (that is, Article 1) protects also legal persons and therefore claim that the state is a legal person that should be protected. Here, I will comment on this only as another illustration of what the Scandinavian approach is not. Such reasoning would be seen as conceptual logic parted from, inter alia, the fundamental fact that the convention is an agreement between states.

11 Again, please note that I give very great weight to the fact that the judges claim that 'the crucial question' is that of ownership of the material. Please note also that I do understand that the legal culture in Strasbourg should not be Scandinavian. I am not saying that the judges have applied bad reasoning; I state only that they did something very different from what a judge would do if taking the Scandinavian approach.

12 The fact that the Swedish and the Finnish judge participated in the decision, and that the registrar was Swedish, does not change this fact. What I describe is an approach to law in general. There is no reason to speculate as to what might have 
interferes with the decision-making process rather than supporting it. This is also an illustration of how difficult the tool is to use. It can be used without no-one even noticing that they use it upside down.

That the concept of ownership is complex and difficult to apply is a central theme in the Scandinavian approach. In fact, one could say that the latter approach was to some extent developed around the concept of ownership. ${ }^{* 13}$ Ownership is always understood in relative terms and as a more specific interest in the relation and context at hand. To underscore this, Scandinavian lawyers even tend to avoid using the concept when dealing with legal issues. ${ }^{*} 14$ Since the relations are kept apart a clearer way is to use words such as 'priority' or refer to a 'better right' of one party with respect to the other.

The case before the Strasbourg court should, with the Scandinavian approach, be resolved with reasoning that balances the interests between individual employees of the state and their employer, the state. At the same time, it should achieve balance between the society's interests in promotion of research and the same society's interest in access to research material. All norms that are found to be relevant should be used in determination of this balance. Since there are norms that point in different directions, the arguments need to be evaluated. One normative argument that would be considered strong is that an employee shall not be able to make his employer bound by a personal promise, especially if that promise goes against statutory law. In the decision-making process, it would be important also to reflect upon such things as the various consequences of the norm that any proposed decision would establish.

There is, of course, much more to be said if one were to try to describe how legal decisions are made. What I have done in this section of the paper is mainly to give an illustration of what the Scandinavian approach is, from the starting point of what it is not. I hope the illustration proves the point. There are reasons for the Scandinavian scepticism about use of the concept of ownership in the construction of solutions. With the Scandinavian approach, we try to not even involve that concept in the legal reasoning.

\section{Transfer of ownership}

The concept 'transfer of ownership' can be used to build solutions for a lot of different legal issues. It can be used as the starting point for a superstructure for the norms that regulate the issues. The structure can make it easy to find a way among the norms, and it can govern how the solutions are constructed in such a way that the process appears to be rendered clear and predictable. These possible advantages are nether the less not good enough for the Scandinavian approach. The Scandinavian approach is to not use the concept at all. We have no superstructure, and we prefer not letting such a concept govern either the solutions or the reasoning.

The Scandinavian way is instead to deal with each issue separately, without connecting the issues to a superstructure that involves ownership. What we do is to use different problem categories to sort and analyse different kinds of issues pertaining to property. ${ }^{*} 5$ These categories are contractual relationships between two parties, non-contractual relationships between two parties, double transfer, unauthorised transfer, priority relative to the transferee's creditors, and priority relative to the transferor's creditors. The

been said among the 17 judges and why they happened to employ argumentation that is so remarkable from a Scandinavian perspective.

13 See, for example, the overview by M. Lilja. National Report on the Transfer of Movables in Sweden. - W. Faber, B. Lurger (eds). National Reports on the Transfer of Movables in Europe, Vol. 5: Sweden, Norway and Denmark, Finland, Spain. Munich: Sellier 2011, pp. 27-31. - DOI: http://dx.doi.org/10.1515/9783866539099.1.

In the same volume, J.-O. Færstad, M. Lilja. National report on the transfer of movables in Norway and Denmark, pp. 214-215. - DOI: http://dx.doi.org/ 10.1515/9783866539099.205. See also the overview in C. Martinson. Transfer of Title Concerning Movables, Part III: National Report: Sweden. Frankfurt 2006, pp. 10-13.

14 See, for instance, K. Rodhe. Handbok i sakrätt. Stockholm 1986, pp. 175-176.

15 The majority of Swedish literature on property law uses this kind of categorisation. Most evident is probably the book by Zetterström, since the title he adopts is 'The four main cases of property law'. S. Zetterström. Sakrättens fyra huvudfall, 3rd ed. Uppsala, Sweden: Iustus förlag 2012. See also T. Håstad. Sakrätt avseende lös egendom, 6th ed. Stockholm: Norstedts Juridik 1996; G. Millqvist. Sakrättens grunder: En lärobok $i$ sakrättens grundläggande frågeställningar avseende lös egendom, 6th ed. Visby, Sweden: Norstedts Juridik 2011; H. Hessler. Allmän sakrätt: om det förmögenhetsrättsliga tredjemansskyddets principer. Stockholm: P.A. Norstedt \& söner 1973. See also the Norwegian monograph by T. Falkanger and A. T. Falkanger. Tingsrett, 7th ed. Oslo, Norway: Universitetsforlaget 2013. For an example of an earlier and different kind of categorisation, see Ö. Undén. Svensk sakrätt, 10th ed. Lund, Sweden: Liber läromedel 1976. See also the old but specific comment in English by F. Vinding Kruse. What does 'transfer of property' mean with regard to chattels? A study in comparative law. - American Journal of Comparative Law 1958, p. 500. 
solutions to these problems are not connected to each other. Each conflict is simply dealt with on its own merits.

This means, for example, that transferee C might win out against transferor B's creditors CR but lose out relative to B's transferor A. The reason for this is simply that we prefer to decide on issues from the starting point of the typical interests in a relationship between two typical parties to a conflict. As we see the situation, the arguments in unauthorised-transfer conflicts differ from the arguments in conflicts on priority before the transferor's creditors.

An effect is in other words that the solutions of two different conflicts are not co-ordinated with each other. This is not something for which we strive. We do, however, see such an effect as rather unproblematic. The alternative-to connect the solutions to each other-is seen as problematic for the same reasons seen in the example I used on the concept of ownership. A connection would mean involving considerations that are not directly relevant for the problem between the parties. They might even interfere with the decision-making process rather than support it.

To illustrate, I will give another example. The background is a real case from a local court, a few years ago.

Party A was in a hire-purchase contract with B for the land and cottage she owned. ${ }^{* 16}$ After a year, $\mathrm{B}$ falsified the documentation such that it appeared that B had bought the property from A and paid for it. B used the falsification to become registered as the owner in the land register. Then, B got her elderly uncle $\mathrm{C}$ to sign some papers that made it seem that he had bought the property from $\mathrm{B}$. After this, $\mathrm{C}$ was registered as the owner in the land register. Some while later, A recognised what had happened and sued C.

$\mathrm{C}$, the elderly uncle, said in the court hearings that he had only helped his sister's daughter out. He also explained that he was very sorry that he could not give A the property back, since it had, by the time of the court proceedings, been sold on to D. Actually, D had, in his turn, even sold the property to E.

In the Scandinavian context, this case is almost as simple as it gets. Since A says that she claims the property and $\mathrm{C}$ says he does not, the decision must be that $\mathrm{A}$ shall be given priority above $\mathrm{C}$.

What A needs to do after this is to sue the one who turned out to be the person having a claim. This is now $\mathrm{E}$. If $\mathrm{E}$ then claims that he has a better right than $\mathrm{A}$, the relation of the two has to be addressed. It would be a rather easy case to decide, since $\mathrm{E}$, according to Swedish legislation, cannot make a good-faith acquisition when B has falsified the documents. ${ }^{* 17}$

The example illustrates how each relation is dealt with separately in the Scandinavian approach. A downside with this might seem to be that people such as A must make claims with respect to several other people and may even have to go to court on multiple occasions. For practical reasons, however, this picture is not entirely accurate. If A resolves her issue with one of the others, preferably the most central of them, this makes it easier to get the others to follow.

Also, there is a special rule with respect to land. According to this rule, A only needs to sue the person who is registered as the owner at the time when A files suit; A need not sue anyone else to whom C sells the property after being sued. The judgement becomes valid also against $\mathrm{D}$ and $\mathrm{E}$. This special rule can be compared to a rule on transfer of ownership. The effects of the rule could be described as a rule that gives A ownership unless C, D, or E makes an acquisition that transfers A's ownership. There is however a fundamental difference since the Swedish system is built from the opposite starting point.

As I have mentioned above, the example of A's sale of land is based on a real case. ${ }^{*}{ }^{18} \mathrm{I}$ have chosen this case since the actual outcome illustrates also another aspect of the concept of transfer of ownership. The case between A and C is an easy case, and A should win, as already noted. Regrettably, the parties did not argue the case very clearly, and they employed the ownership concept. The local court judge ended up deciding that A should not get what she claimed, since $\mathrm{C}$ did not own the property. The decision is just two short sentences and it is not logic. The only way to get it to become logic is to read it with an implied understanding that, since $\mathrm{C}$ is not the owner, he cannot give ownership back. That line of thinking is a mistake. It

16 This is not a commonplace type of contract in the context of Swedish land transactions; the parties happened to choose terms of this sort.

17 I have elaborated on this theme in C. Martinson. Funktionalismen och bättre rätt till fast egendom. Svensk Juristtidning 2008, pp. 669-687.

18 Mariestads tingsrätts dom 2006-11-08, målnummer T28-06. To refine the example, I have made the choice above to modify the circumstances slightly in the telling. In actuality, it seems likely that $\mathrm{B}$ falsified the documentation such that $\mathrm{C}$ appeared to be the one who bought from $\mathrm{A}$. 
illustrates that it might not be so intuitive to follow the Scandinavian approach. To avoid ownership in the analysis is not always easy. The case therefore also illustrates that the concept can lead one's thought into conceptual logic. Norwegian professor Sjur Brækhus expressed the problems we sometimes experience as if the concept of ownership has 'a strong influence over the mind'. ${ }^{*} 19$

From the Scandinavian perspective, it is, in fact, not only the concept of ownership that creates these kinds of problems. Legal concepts do affect our way of understanding reality. On the other hand, this effect is something we need. All legal concepts are, of course, to some extent, normative simplifications that should be used. The legal concepts are central to law. Without them, law would not be law. It would at least be very different. The reason for which the Scandinavian approach sees some concepts as problematic is that the underlying ambition of the Scandinavian approach is realism. It is seen as important that the law be fairly close to the real concerns associated with a specific problem. Transfer of ownership is one concept that has been evaluated from this perspective, and it has been found to be more problematic than helpful.

While this might seem to be a strange choice, at least we Scandinavians are not alone. The thinking behind US law is somewhat similar where transfer of ownership is involved. The US law professor Karl Llewellyn put it thus:

Unless a cogent reason be shown to the contrary, the location of title will govern every point which it can be made to govern [...]. The burden is put upon any individual issue to show why it should be honored by being severed from the Title-lump in any particular, and given individualized treatment. Now this would be an admirable way to go at it if the Title concept [...] had been tailored to fit the normal course [...]. But Title was not thus conceived, nor has its environment of buyers and sellers had material effect upon it. It remains, in the sales field, an alien lump, undigested. It even interferes with the digestive process. ${ }^{* 0}$

\section{Unjustified enrichment}

Another concept that is problematic from the Scandinavian standpoint is that of unjustified enrichment. It is a concept unfit for the Scandinavian legal environment. One reason for this is that we do not use a transfer-of-ownership superstructure. Since we deal with the relations one by one, we already include the arguments as to what may lead to unjust results in our analysis from the beginning.

Another reason we find unjustified enrichment unsuitable is that it is not a good tool for directing behaviour. There are other methods and incentives to prevent people from doing such things as using other people's property.

A third reason is that we find it better to keep issues separate from each other. They should be dealt with specifically in the context of the kind of relationship the issues have to do with. Unjustified enrichment seems to be a concept that is so broad and blunt that its use is risky.

The conclusion that unjustified enrichment is unfit for the Scandinavian legal environment could be claimed to be scientifically proven. Two Scandinavian researchers draw this conclusion in their theses in 1950. ${ }^{{ }_{21}}$ Interestingly, the concept has nonetheless been gaining supporters in recent years. They claim that there are reasons to conduct a new evaluation and that it is now time to review what they see as old and out-dated arguments. ${ }^{* 2}$

I will return to the issue of critics and supporters, but first I would like to give a glimpse of how we approach these issues. Again I will use an example from a real case: ${ }^{*} 3$

An oil company delivered 15,951 litres of diesel fuel to a farm. This delivery was a mistake-the delivery should have been to another site. When the oil company realised the mistake, they charged the receiving

19 S. Brækhus. Omsetning og kredit 3 og 4, omsetningskollisjoner I og II. 1998, p. 6.

20 K. Llewellyn. Through title to contract and a bit beyond. - New York University Law Quarterly Review 1938 (15), p. 169.

21 J. Hellner. Om obehörig vinst särskilt utanför kontraktsförhållanden. Stockholm, Sweden: Almqvist \& Wiksell 1950; A. Vinding Kruse. Restitutioner: et bidrag til undersøgelsen af berigelsesgrund- sætningen i dansk og fremmed ret. Copenhagen, Denmark: Gads forlag 1950.

22 M. Schultz. Nya argumentationslinjer i förmögenhetsrätten. Obehörig vinst rediviva. - Svensk Juristtidning. 2009, pp. 946959; J. Munukka. Är obehörig vinst en svensk rättsprincip. - Ny Juridik 2009/3, pp. 27-34.

23 Attunda tingsrätts dom 2008-05-22, målnummer T673-07. 
farmer, but the farmer refused to pay. Since the parties could not come to an agreement, the case was decided in the local court. The decision was, in the part relevant here, very brief:

By using the diesel without paying for it [the farmer] made such an economic gain that he, according to general private-law principles on unjustified enrichment, reasonably should have to pay.

The decision does not follow the Scandinavian approach. In fact, it is rather remarkable that the judge refers to unjustified enrichment. More important, however, is that the example shows something that the critics of this concept have claimed for decades. If we accept this concept, lawyers will stop analysing the issues and instead just decide by using the concept. The results might then be rather haphazard. One could, for example, argue that it is actually the oil company who make an unjust profit, since they forced the farmer to, in effect, become their customer.

If the diesel case were to be handled in a Scandinavian functional way, the analysis could involve addressing circumstances such as these: Whose mistake was it that the diesel was used? Was someone careless? To what extent was the use made knowingly? At what point in the course of events did any of the parties respond to the wrongful delivery, and how? Was it before or after the farmer started to use the fuel? What consequences would a norm built on the decision lead to? How would people in the diesel market behave if one were to make a decision of a certain kind? Who would stand what risk if the decision were to be one way or the other? How frequent could cases such as these become? What sums do they involve?

In other words, the Scandinavian approach deals with these issues contextually. In the Scandinavian legal systems, there are, in my opinion, rather few examples of problems with unjustified-enrichment issues. It is always hard to say something about the reality from the empirical evidence of a lawyer, but it is a fact that the concept of unjustified enrichment has not been used in our tradition. We have managed without it.

As I mentioned in the beginning, there is, however, some debate on the issue nowadays. Some hold that the Supreme Court actually did use the idea of unjustified enrichment in an obiter dictum and also made one or two decisions wherein they used such a principle. Others hold that this just wishful thinking. The debate has not come very far yet. ${ }^{* 4}$ I could illustrate this by describing a debate I participated in myself. A professor who is in favour of the concept of unjustified enrichment used this simile: 'We should wake "the corpse" and see how it will solve thousands of legal problems that we have!' Since I represented the other side in the debate, I replied: 'But isn't it enough to imagine the results we will get if we ask a corpse to solve thousands of legal problems?'

In any case, there is reason to do more research into how we actually handle these problems. This is already one subject of research projects, but more could be done. ${ }^{* 25}$ Among the important reasons for doing this research is that we must be able to communicate with lawyers internationally on how we deal with these issues. ${ }^{* 26}$ Another reason is that Scandinavian law is under such international influence that we need to remind ourselves of what we actually have instead. To some Scandinavian lawyers it might now seem that our law is underdeveloped. Under such circumstances, it is easier to prefer to have something before not having something. It can therefore appear easier to have the concept than to refrain from it.

\section{The coming into existence of a claim}

'The coming into existence of a claim' is a long-winded way of expressing a concept. This concept is applied nonetheless and can be found in, for example, the DCFR. ${ }^{* 27}$ For the Scandinavian approach, this concept might well be the most troublesome one of all to deal with. From what I have described so far, it follows that the Scandinavian approach strives after not letting conceptual logic be decisive. That outcome is hard

24 Another reason can be illustrated by the Finnish experience, wherein the concept is used but at the same time criticised, in such a way that the situation can be described as exhibiting strong dualism. This dualism is seen as unproblematic in practice, however, since the question has never been a big issue. T. Wilhelmsson. Comment at Nordiska Juristmötet 2008 (p. 438 in the proceedings document Nordiska Juristmötet 2008). See http://jura.ku.dk/njm/38/monsen-erik/ Debat i pdf-format.

25 See, for example, E. Monsen. Berikelseskrav. Vederlagskrav og vinningsavståelseskrav ved urettmessig utnyttelse av ting og rettighet. Oslo, Norway: Cappelen Akademisk Forlag 2007; E. Monsen. Uberettiget berigelse (obehörig vinst) som grundlag for betalingskrav. - Nordiska Juristmötet 2008, pp. 337-353. See http://jura.ku.dk/njm/38/monsen-erik/.

26 Compare T. Wilhelmsson (see Note 24), p. 439.

27 DCFR III - 5:106. 
to avoid, however, when the concept is all about describing whether a relation includes something or not. Since we need to communicate whether the relation at a certain point in time involves a claim or not, it is hard to avoid the concept.

For this reason, the Scandinavian legislators have not been able to avoid the use of the concept in their legislation. It is probably fair to say that there has not even been such an ambition of avoidance. We do have several rules wherein the legislator has used the term 'the coming into existence of a claim'. The Act on General Limitation is one of these, and another is the actio Pauliana rule on rescission of security given to a creditor for existing debt. One can find rules of this sort in diverse fields of legislation, among them marriage law, the law of succession, an act on promissory notes, the law of legal procedure, and debt enforcement law.

The Scandinavian approach to rules such as these is to hold that the concept is dependent on the purpose of the rule. This means that we have no general idea as to when a claim comes into existence. Instead we say that the moment in time differs with the context. In theory, one result could be described as a specific claim being able to be seen as coming into existence at different times when we use different rules.

What I have just said might seem remarkable, or worse. The logic behind this approach is, however, that we prefer being able to decide on the solution to a problem with priority to the real interests in the relevant context. The directly relevant arguments should be decisive. It is of low relevance to hold that it has been decided that the claim came into existence at a certain point in time in relation to another kind of conflict than the one at hand. As I have explained when considering transfer of ownership, we like to deal with each issue separately, without connecting the issues to a superstructure. The coming into existence of a claim is such a superstructure. Unlike when dealing with the concept of transfer of ownership, we do use the phrase 'coming into existence of a claim'. In actuality, we even use the concept. What we do, however, is to use it contextually.

To illustrate the approach, I shall give an example. There is a real case behind this example too: ${ }^{* 28}$

A supplier of clothing and a clothing store made a contract in March 2004. The supplier undertook to make deliveries of clothing on certain dates. Deliveries were made for a time, up until December 2004, when the clothing store went bankrupt. It was a private limited company. Under Swedish law, an owner can become personally liable if continuing to do business with a nearly insolvent company unless he completes certain formalities and investigates the financial situation. The owner of the supplying company had not done this. Therefore it was claimed that he should be liable for all debt that had come into existence in the final months before the bankruptcy.

The legislation stipulates liability for all claims that have come into existence during a certain period. Two alternatives were discussed in connection with the case at hand. One alternative was that the claims proceeding from the contract came into existence when the parties signed the contract. The other alternative was that they came into existence when each respective delivery was made. In the latter case but not the former, the owner would be liable.

The case I refer to was settled out of court, but there is illustrative argumentation to be considered from the case nevertheless. It is from a legal opinion that the store obtained from a former president of the Supreme Court. ${ }^{* 29}$

The former president began his reasoning by pointing out that the purpose of a rule can be of importance when one is determining the time at which a claim came into existence. After this, he claimed that the direct purpose of the rule in question is to protect the creditors by giving some creditors security. He also claimed that the indirect purpose is to provide an incentive to investigate the financial situation. According to the former president, these purposes should not be seen as of any 'special nature'. Accordingly, he argued, there is no reason for divergence from the ordinary view on when a claim comes into existence. This is the day the contract is signed. With a possible exception for contracts that can be terminated through notification, the former president claimed that this is 'generally the most natural' solution.

This one paragraph describes the essence of the argument. What the former president does, in other words, is to argue that, in essence, there is a natural resolution of the issue. The remainder of the eleven pages consists of briefs on what other authors have claimed in legal doctrine and of comparisons with other rules wherein the coming into existence of a claim is a requisite.

\footnotetext{
28 The case seems to have been settled, but it was first tried in Stockholms tingsrätts dom 2009-02-18, målnummer 14-935-06, and appealed to Svea Hovrätt, 2009-03-10.

29 Legal opinion of T. Gregow. Received by Stockholms tingsrätt, 2008-03-26, in the case mentioned.
} 
From the critical point of view that I adopt here, the conclusion is that even the best of Scandinavian lawyers struggle with the concept. The Scandinavian approach is definitely not to deal with issues by deciding what is the most 'natural'. That would be equivalent to deciding on something other than the real issue.

The real question to ask is another one. It could be put this way: Should an owner of a private limited company be personally liable for deliveries that he receives in accordance with an existing contract if said owner fails to perform the statutory investigations into the financial situation?

This question should be dealt with through consideration of elements such as the consequences, the frequency, the size of the liability, possible effects on the market, and so on. If the decision is that he should be liable, the claim should be seen to come into existence when the deliveries were received, and vice versa.

The effect of the approach as described might seem remarkable. It should be noted, therefore, that the relevant liability rule in the Swedish Companies Act has been questioned. It has been held that it would be much better to rewrite the rule and make it more in accordance with the real question. The rule could be instead that the people behind a company should be liable if they act negligently toward others when they ought to know that the other company is going bankrupt. ${ }^{*} 30$

Regardless, there is, of course, reason to question the Scandinavian approach when one considers how we use the concept of the coming into existence of a claim. Indeed, some Scandinavian lawyers have done so in recent years. ${ }^{*} 31$ They ask whether it wouldn't be better to actually build the system on a simple principle-e.g., that all contractual claims come into existence when the contract is signed. If this is taken as the starting point, the legislator could make deviations from this point where finding it necessary. So far, this critique has not had much impact. The axiomatic counter-argument is that there are so many situations wherein the concept might be relevant that it is very hard to foresee what the needs for deviations might be and that this situation could lead to an increased risk of problems being solved through conceptual reasoning rather than consideration of the real issues.

\section{Accessio}

The next concept to explore is accessio. Most Swedish lawyers do not know what this concept means. After all, we have used it very little. Our rules on accessio are limited to a few specific contexts, and even then we do not use the word. The reason for this is that the Scandinavian approach deals with relations. Accessio pertains to objects, and objects should not be at the centre of attention; people should. Again, objects are conceptual. This entails a risk of the definitions of objects becoming the means of deciding the outcome of a conflict.

To illustrate the Scandinavian approach to accessio issues, I will use an example invented for a textbook: B sells old cars. The car stereo in one of the cars is nice, so A buys just the stereo. B and A agree to leave the stereo in the car until the next week. When B sells the car the next day, he forgets about the matter. The buyer of the car, C, takes the car with him.

A Scandinavian lawyer would deal with this case as a good-faith acquisition. The relationship between people is what should be dealt with. For us, it would be strange to start dealing with the case by deciding that the stereo is a part of the car until being removed from it.

This does not mean that the problem of accessio disappears. On the basis of the Swedish Act on Acquisition of Chattels in Good Faith, A shall have a more or less limited priority. If $\mathrm{C}$ acted in bad faith, A shall have direct priority before $\mathrm{C}$, and if $\mathrm{C}$ acted in good faith, $\mathrm{A}$ shall have the right to pay $\mathrm{C}$ and thereby obtain the stereo. The reason that these problems have not been given much attention lies in the nature of the Scandinavian approach. These problems do not arise frequently, and the parties deal with the situation pragmatically in many cases. In the event that $\mathrm{A}$ has to pay $\mathrm{C}$ in order to obtain the stereo, A would probably not wish to pay the value of the stereo and the costs that $\mathrm{C}$ will incur. In the case of $\mathrm{A}$ being given direct priority, the problem might be resolved by C paying $\mathrm{A}$.

As you can see, this is not an elaborate way of dealing with these issues. There is, however, a general preference here too. Do not create norms on issues that have had little practical importance. The

3o As suggested by S. Lindskog in his speech at Göteborgs Domarakademi, in Gothenburg on 19 September 2011.

31 See, for example, M. Schultz. Skadeståndsfordrans uppkomst. - Juridisk Tidskrift 2010/11, pp. 870-889; J. Heidbrink. Tankar om kontraktfordringars uppkomst. - Juridisk Tidskrift 2010/11, pp. 858-869. 
Scandinavian legislator has applied this policy for a long time, and said policy is in this respect comparable to common law.

Still, we do have some specific rules on accessio. There are rules on what should be seen as a part of land or a part of buildings. There are also rules for ships and aeroplanes. Interestingly, these rules can be described as a mix between the relational and the conceptual. The rules for land and buildings draw a distinction between objects in light of the background: objects that have been attached by someone other than the landowner can be excluded from accession. The same goes for objects that the landowner attached without regard for the fact that someone else claims them. ${ }^{*} 32$

It should be pointed out also that we might now see development of a more general principle affecting accession. The general problem has been raised in Scandinavian legal research. ${ }^{*} 33$ A principle of accessio is not something strange to have in the Scandinavian environment. It just needs to mesh well with the relational starting point of the Scandinavian approach.

\section{Traditio}

The concept of traditio is used somewhat differently between the individual Scandinavian countries. Here, I will look only at traditio in Sweden and only at the buyer's position in the case of the seller's bankruptcy. The latter example illustrates both the strengths and the weaknesses of the approach.

The Swedish principle of traditio has to a large extent been developed by judges' decisions. Over the last 50 years, this development has increasingly been driven by the argument that traditio prevents creditor fraud. The deciding issue when one is drawing the line for priority has, therefore, become whether the seller is cut off from his possibilities for controlling and disposing of the goods. This is a problematic norm, since the Swedish traditio principle does not leave room for agreements to leave the goods with the seller. What the buyer can do is register an acquisition when the goods are left with the seller, but the registration rules are not suitable for every kind of transaction. In some situations, it has, therefore, been hard to figure out what to do.

One category of difficult transactions has involved two companies with the same person as the sole owner. Since the owner controls the goods and can dispose of them for the selling company after the transaction, some have held that the company buying the goods should not get priority. This was consequential to the conception that cutting off the possibility to control and dispose of the goods should be decisive.

When the Supreme Court finally, in 2007, got a chance to decide on a refined case, they gave priority to the buying company. ${ }^{*} 34$ They reached this decision by using the above-mentioned control and dispose argument. Since the owner of the company would be liable for embezzlement if he disposed of the goods for the selling company, the selling company had lost enough of its control. The judges pointed out that it was important that the crime would truly be embezzlement and not the milder form of offence-disposing of property to the detriment of someone else's right. They meant that the decision would not be consistent if the milder form had been enough, since every seller is liable for that offence if he disposes of what he has already sold. If the boundary were drawn there, there would, according to the judges, never be a need to fulfil the requirements of traditio and registration for 'all transactions'.

The decision is in line with the Scandinavian approach. What the judges do is see function as more important than form. The transaction has the effect of the owner having less incentive to dispose of the goods for the seller's account.

There is, however, much that can be said about the reasoning in this case, also from the perspective of the Scandinavian approach. In many ways, the decision is actually not a very characteristic one in this legal culture.

One central point of criticism has to do with the argument that all transactions would be affected by the resolution of this case. This claim is not at all characteristic of the Scandinavian approach, and one could question whether this is really what the judges mean. The judges may well have decided that transactions between companies that have the same representative are exempt from traditio in certain circumstances.

\footnotetext{
Jordabalken 1970:994, Chapter 2.

P. Strömgren. Tillbehör och accession. Uppsala, Sweden: Iustus förlag 2012.

Supreme Court case NJA 2007, p. 413.
} 
Since the rest of the judges' arguments in the case pertain mostly to the usefulness of transactions of this kind and point out that there are other rules that protect the creditors, the judges could simply have decided that there was enough reason to make an exemption. The ability to make contextual exemptions of this type is actually a major concern in the Scandinavian approach! Indeed, it is quite possible that the decision will indeed be interpreted in this way, as an exemption for transactions between two companies with one and the same person as the sole owner.

Also, there were obvious arguments that the judges did not contemplate, even though they had been used by the Supreme Court judges in a case 12 years earlier, $1995 .{ }^{*}{ }^{35}$ In that case, the judges argued that the cutting off (of the seller's control and possibility for dispose) need not be full and complete for the condition to be met. It was enough if the control and dispose possibilities were reduced, as long as the probability of being able to confirm that there had been a transaction was high and also information on the transaction had been disseminated to some extent.

It is possible to describe the differences as if the judges had employed two distinct norms. The judges in the later case, from 2007, used a cutting-off principle. The judges in the earlier case, in contrast, applied a broader norm that could well be described as a traditio principle. ${ }^{*} 36$

What the two decisions illustrate, inter alia, is that the choices are not obvious when one creates a solution via the Scandinavian approach. There are difficulties in deciding on what actually should be seen as functional. The Scandinavian approach, as every other approach does, has its difficulties and weaknesses.

\section{Contrasting of approaches, a route to a better understanding of law}

I have illustrated a few things about the Scandinavian approach by explaining how we handle six common legal concepts. Some of these concepts are not used in the Scandinavian approach, since we simply approach the issues in a relational and contextual manner. The concepts that we do use are also used in a relational way, with contemplation of the context.

It is hard for me to say whether it is useful for lawyers from other legal cultures to learn about the Scandinavian approach. I do, however, believe that it can be good to contrast the approach found in one culture with the approaches that others utilise. At its base, this has to do not only with legal culture but also with the understanding of law and what law is.

5 Supreme Court case NJA 1995, p. 367.

36 It could be noted that a committee is now working on a governmental proposal to abandon the principle of traditio. See Justitiedepartementet, Kommittedirektiv 2013:28 Köparens rätt till varor i förhållande till säljarens borgenärer. 